Available online at http://journal.stkip-andi-matappa.ac.id/index.php/histogram/index

Histogram: Jurnal Pendidikan Matematika 4(2)., 2020, 518 - 526

\title{
PEMBELAJARAN DARING MASA DARURAT COVID-19 PADA MAHASISWA PENDIDIKAN MATEMATIKA
}

\begin{tabular}{c} 
Arbain 1* $^{*}$ Farman' \\
${ }^{1,2}$ Universitas Sembilanbelas November Kolaka \\
* Corresponding Author. Email: abughazwanalhasan@gmail.com \\
Received: 05 Agsustus 2020; Revised: 15 September 2020; Accepted: 30 September 2020 \\
\hline
\end{tabular}

\section{ABSTRAK}

Penelitian ini merupakan penelitian kualitatif deskriptif dengan menggunakan metode survey secara online. Penelitian dilakukan guna memperoleh gambaran mengenai penerapan pembelajaran daring di Program Studi Pendidikan Matematika Universitas Sembilanbelas November Kolaka saat darurat Covid-19. Data dikumpulkan melalui kuisioner berupa Google Form dan wawancara melalui telepon. Analisis data dilakukan menggunakan teknik interaktif Miles \& Huberman. Hasil penelitian menunjukan bahwa pembelajaran daring mendapat tanggapan postif dan negatif dari mahasiswa. Tanggapan yang bernada positif diperoleh untuk aspek-aspek antara lain ketersediaan perangkat mobile, penyampaian materi, interaksi, kemudahan kuliah daring, manajemen waktu, pengorganisasian kelas, kaktifan, kemandirian dan fleksibilitas. Adapun aspek-aspek yang mendapat tanggapan negatif dari responden adalah tugas, penjelasan tugas serta beban kerja, penguasaan materi, koneksi internet, biaya paket data, dan distraksi.

Kata Kunci: Pembelajaran Daring, e-Learning, Covid-19

\section{ABSTRACT}

This research is using descriptive qualitative methods through an online survey. The study was conducted to find an overview of the application of online learning in the Mathematics Education Study Program of the Universitas Sembilanbelas November Kolaka during the Covid-19 emergency. Data collected through questionnaires in the form of Google Forms and interviews by telephone. Data analysis was performed using the Miles \& Huberman interactive technique. The results showed that online learning received positive and negative responses from students. Positive responses were obtained from some aspects including the availability of supporting devices, delivery of material, interaction, ease of lecture, time management, class organizing, activeness, independence, and support. Aspects that received negative responses from respondents were assignments, job descriptions and workloads, mastery of the subject materials, internet connection, internet costs, and distraction.

Keywords: Online Learning, e-Learning, Covid-19

How to Cite: Arbain., \& Farman. (2020). Pembelajaran Daring Masa Darurat Covid-19 Pada Mahasiswa Pendidikan Matematika. Histogram: Jurnal Pendidikan Matematika, 4(2), 518 - 526, doi: http://dx.doi.org/10.31100/histogram.v4i2.720

Permalink/DOI: http://dx.doi.org/10.31100/histogram.v4i2.720

\section{PENDAHULUAN}

Penyebaran wabah virus corona (Covid-19) di Indonesia turut mempengaruhi berbagai aspek kehidupan mulai dari bidang ekonomi, sosial, bahkan bidang pendidikan. Berbagai upaya ditempuh pemerintah untuk menekan dan memutus rantai penularan Covid-19 yang mempunyai sifat penularan yang mudah dan cepat. Salah satunya adalah memberlakukan kebijakan pembatasan sosial (social distancing) di berbagai bidang. Himbauan untuk tetap di rumah (stay at home) dan protokol kesehatan selama masa darurat covid-19 terus dikampanyekan dengan masif. Misalnya di bidang pendidikan tinggi,

Direktur Jenderal Pendidikan Tinggi Kementerian Pendidikan dan Kebudayaan CopyrightC 2020, THE AUTHOR (S). This article distributed under the CC-BY-SA-license. 


\section{Histogram: Jurnal Pendidikan Matematika, 4 (2), 2020 - 519 \\ Arbain $^{1 *}$, Farman ${ }^{2}$}

mengeluarkan surat edaran Nomor 1 Tahun 2020 tentang pencegahan Corona Virus Disease (Covid-19) di perguruan tinggi. Dalam surat edaran tersebut, seluruh perguruan tinggi dihimbau agar memberlakukan pembelajaran jarak jauh selama masa darurat covid 19. Banyak perguruan tinggi melakukan penyesuai proses perkuliahan yang semula dilakukan dengan tatap muka di dalam kelas secara lansung menjadi perkuliahan daring (online), termasuk Universitas Sembilanbelas November Kolaka (USN Kolaka). Hal ini memberi kemudahan kepada mahasiswa untuk mengikuti protokol kesehatan karena mereka dapat belajar dari rumah masing-masing.

Pelaksanaan pembelajaran jarak jauh di USN Kolaka merujuk pada surat edaran Rektor Nomor: 488/UN56/SE/2020 tentang Pelaksanaan Tri Dharma Perguruan Tinggi Saat Pandemi Covid-19. Pembelajaran daring dilakukan melalui media pembelajaran atau aplikasi seperti aplikasi WhatsApp, Telegram, Google Classroom, Edmodo, dan Video Converence. Aplikasi-aplikasi dan media pembelajaran tersebut dalam penggunaannya dapat dipadukan antara satu aplikasi dengan aplikasi lainnya untuk mencapai kualitas pembelajaran yang baik. Misalnya, mengingatkan jadwal perkuliahan dan diskusi menggunakan Grup WhatsApp atau Grup Telegram, melakukan absensi, share materi, dan penilaian menggunakan Google Classroom atau Edmodo, dan untuk materi kuliah yang perlu audio visual dapat menggunakan aplikasi Video Conference.

Pembelajaran jarak jauh melalui penggunaan jaringan internet atau dikenal dengan pembelajaran daring telah dikemukakan oleh beberapa peneliti. Misalnya, (Moore et al., 2011); (Anshori, 2016); (Pribadi, 2017) menyatakan bahwa penggunaan media internet pada pembelajaran jarak jauh memungkinkan proses transver ilmu dan informasi antara instruktur dan mahasiswa terjadi secara fleksibel. Lebih lanjut, (Milman, 2015); (BrizPonce et al., 2017); (Abdul Latip, 2020) menyatakan bahwa penyelenggaraan pembelajaran daring tidak dapat dilepaskan dari penggunaan teknologi serta fasilitas pendukung berupa komputer, laptop dan smartphone. Melalui perangkat-perangkat mobile tersebut serta dengan dukungan jaringan internet, proses perkuliahan dapat berlansung dalam kelas-kelas virtual menggunakan aplikasi WhatsApp, Telegram, Google Classroom, Edmodo, dan media-media pembelajaran lain (Al-Said, 2015); (Gon \& Rawekar, 2017); (Graham \& Borgen, 2018); (Aghajani \& Adloo, 2018); (Hapsari \& Pamungkas, 2019).

Penerapan kebijakan pembelajaran daring di USN Kolaka menjadi tantangan tersendiri, mengingat sistem pembelajaran daring ini pertama kali dilakukan di USN Kolaka. Para dosen perlu mendesain ulang skema pembelajaranya yang semula direncanakan secara tatap muka menjadi pembelajaran dalam jaringan (daring). Selain itu, 


\section{Histogram: Jurnal Pendidikan Matematika, 4 (2), 2020 - 520 \\ Arbain $^{1 *}$, Farman ${ }^{2}$}

sosialisasi kepada mahasiswa mengenai kuliah daring juga turut dilakukan sehingga diharapkan mahasiwa dapat mempersiapkan diri dengan baik. Kesiapan Institusi dan sumber daya yang ada di dalamnya tentu akan mempengaruhi keberhasilan penerapan kebijakan belajar dari rumah. Menurut (Jamaluddin et al., 2020), kendala yang terjadi dalam proses pembelajaran mempengaruhi minat belajar mahasiswa. Untuk itu, peneliti melakukan kajian untuk memperoleh informasi mendalam mengenai penerapan pembelajaran daring di USN Kolaka pada Prodi Pendidikan Matematika.

\section{METODE PENELITIAN}

Jenis penelitian ini adalah penelitian kualitatif deskriptif. Penelitian dilakukan sebagai bahan evaluasi terhadap penerapan pembelajaran daring di Prodi Pendidikan Matematika USN Kolaka saat darurat Covid-19. Pada penelitian ini, gambaran mengenai penerapan pembelajaran daring dideskripsikan apa adanya, tanpa manipulasi maupun perlakuan tertentu. Evalusi dilakukan dengan memberikan kuisioner kepada mahasiswa mengenai penerapan pembelajaran daring berupa Google Form. Kuisioner disebarkan kepada mahasiswa melalui Grup WhatsApp dengan total responden sebanyak 86 orang. Ada tiga perintah atau pertanyaan yang diajukan pada kuisioner : (1) Bagaimana dukungan perangkat mobile dalam penerapan pembelajaran daring; (2) Uraikan pengalaman kalian selama pembelajaran daring; dan (3) Tuliskan hal-hal yang sudah baik dari sistem pembelajaran daring dan hal-hal yang dianggap kurang termasuk kendala yang dihadapi. Hasil survey kemudian dikelompokkan ke dalam dua kategori respon mahasiswa, yaitu respon positif dan respon negatif.

Penelitian ini dilaksanakan pada bulan Mei 2020 bertempat di Prodi Pendidikan Matematika USN Kolaka. Subjek penelitian ini adalah 86 mahasiswa Pendidikan Matematika USN Kolaka yang aktif kuliah daring saat darurat Covid-19. Selanjutnya dipilih empat mahasiswa untuk diwawancarai agar memperoleh informasi secara mendalam mengenai penerapan pembelajaran daring saat darurat Covid-19. Empat orang mahasiswa yang dipilih berdasarkan pengkategorian hasil survey menurut respon positif dan respon negatif yang terdiri atas dua mahasiswa dengan respon positif dan dua mahasiswa dengan respon negatif. Kegiatan wawancara dilakukan secara daring melalui telepon.

Data dalam penelitian ini berupa hasil respon mahasiswa yang dikumpulkan melalui kuisioner evaluasi penerapan pembelajaran daring dan data hasil wawancara beberapa mahasiswa. Teknik analisis data yang digunakan adalah model analisis Miles dan Huberman (Sugiyono, 2016) yang terdiri dari tiga tahapan sebagai berikut: (1) Reduksi 


\section{Histogram: Jurnal Pendidikan Matematika, 4 (2), 2020 - 521}

Arbain1*, Farman²

data, yaitu dilakukan analisis terhadap hasil survey, selanjutnya dikelompokkan dengan menggunakan dua jenis kode. Kode pertama terkait nada tanggapan mahasiswa yaitu positif dan negatif, sedangkan kode kedua terkait dengan inti tanggapan mahasiswa. Kode positif dipasangkan pada tanggapan-tanggapan yang mendeskripsikan hal-hal yang baik sedangkan kode negatif dipasangkan pada hal-hal yang kurang baik serta bersifat saran atau berupa kritikan. (2) Penyajian data, yaitu hasil survey mengenai pelaksanaan pembelajaan daring disajikan sebagai bahan wawancara. (3) Verifikasi, dilakukan dengan metode triangulasi yaitu melakukan pengecekan antara hasil survey dengan hasil wawancara.

\section{HASIL DAN PEMBAHASAN}

Hasil analisis data kuisioner yang disajikan pada gambar 1 menunjukkan bahwa tanggapan mahasiswa lebih mengarah kepada hal-hal yang positif dari pada yang negatif, yaitu dengan rasio $58.94 \%$ berbanding $41.06 \%$. Tema-tema yang sering dibicarakan dalam tanggapan mahasiswa antara lain mengenai ketersedian perangkat mobile, penyampaian materi, tugas, koneksi internet, penguasaan materi, biaya paket data, dan kemudahan kuliah daring. Secara lebih lengkap tema-tema yang mucul dalam respon mahasiswa terhadap kuisioner yang diberikan disajikan pada gambar 2 .

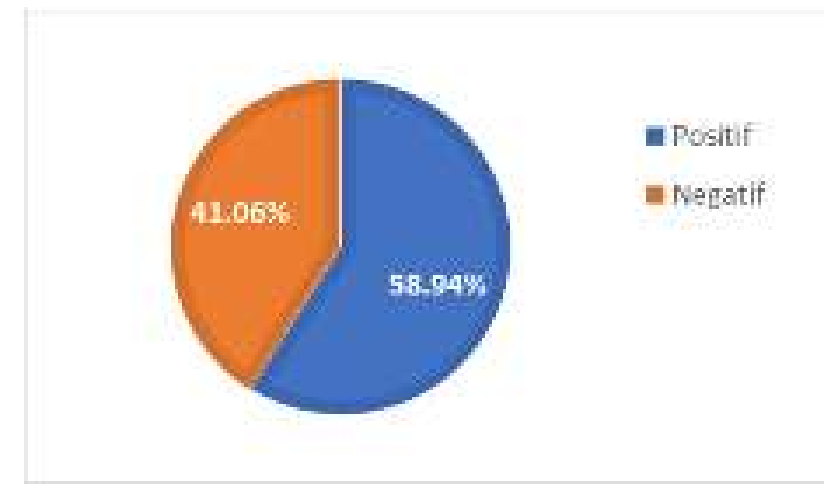

Gambar 1. Proporsi tanggapan positif dan negatif

Berdasarkan gambar 2 dapat dilihat bahwa hampir semua tanggapan mahasiswa yang membicarakan ketersedian perangkat mobile merupakan tanggapan bernada positif. Hal ini menunjukkan bahwa dukungan perangkat mobile dalam pelaksanaan pembelajaran daring pada mahasiswa Pendidikan Matematika USN Kolaka sangat memadai. Hampir semua mahasiswa menyatakan telah memiliki smartphone dan sebagian besar juga memiliki laptop. Dengan dukungan perangkat mobile tersebut, mahasiswa dapat mengikuti pembelajaran secara daring menggunakan aplikasi-aplikasi pembalajaran online. 


\section{Histogram: Jurnal Pendidikan Matematika, 4 (2), 2020 - 522 \\ Arbain1*, Farman²}

Pengintegrasian media dan teknologi pembelajaran penting untuk keberlansungan pembelajaran online (Yaumi, 2018).

Dari wawancara dengan empat responden yang terpilih diperoleh informasi mengenai proses perkuliahan daring bahwa pembelajaran daring lebih sering menggunakan perpaduan WA Grup dan Google Classroom sebagai media pembelajaran. Aplikasi WhatsApp yang sudah dikenal luas dan dipakai mahasiswa sebagai media komunikasi baik personal maupun grup bahkan sebagai media sharing informasi bersifat file dokumen, audio, serta audio visual memudahkan dosen dan mahasiswa untuk berkirim materi perkuliahan berupa softcopy, voicenote, diskusi dan tanya jawab. Begitu juga dengan media Google Classroom, dengan fitur penyimpanan yang memadai dapat mengarsipkan konten pembelajaran berupa file dokumen, audio, dan video sehingga memungkinkan mahasiswa dapat mengakses konten pembelajaran secara berulang. Beberapa aplikasi yang juga digunakan dan dipadukan dengan aplikasi WhatsApp dalam proses perkuliahan daring adalah Edmodo, Schoology, dan konferensi video menggunakan Zoom.

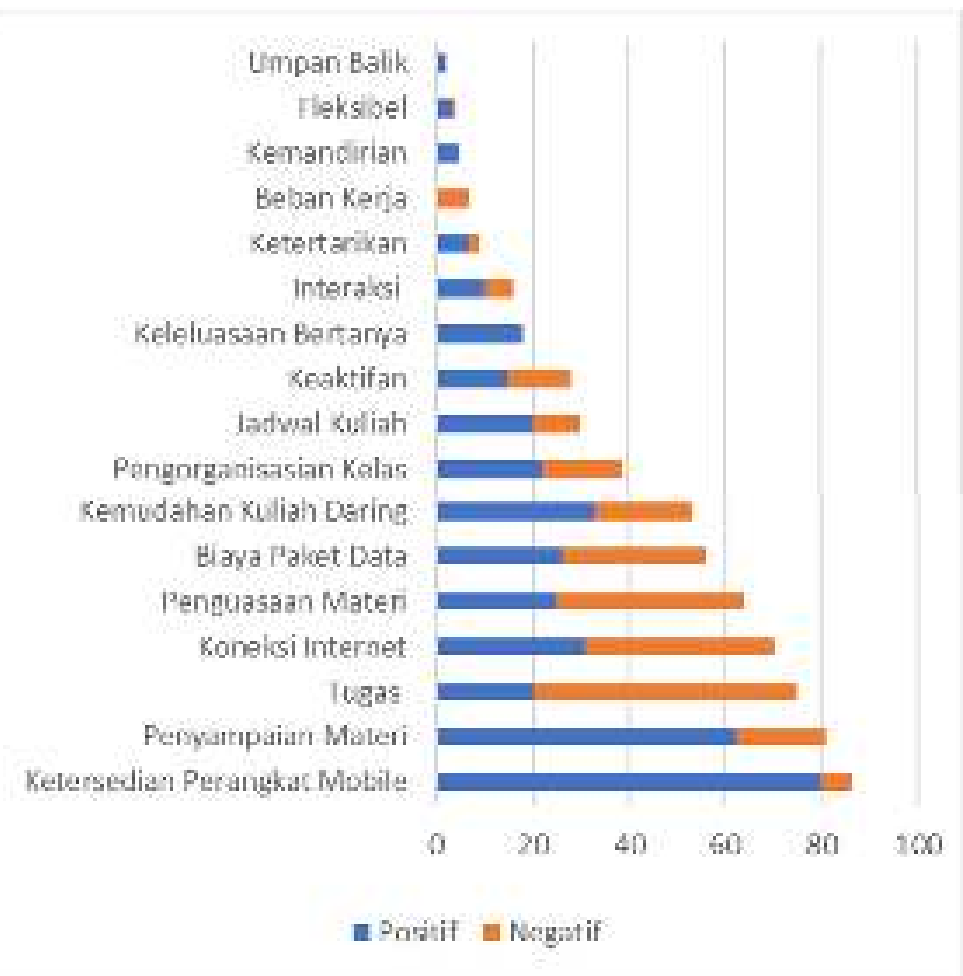

Gambar 2. Tema-tema tanggapan mahasiswa

Selain ketersediaan perangkat mobile, tema lain yang mendapat tanggapan bernada positif, yaitu penyampaian materi, kemudahan kuliah daring, pengorganisasian kelas, dan interaksi. Disini, mahasiswa menganggap usaha penyampaian materi oleh dosen cukup baik. Mahasiswa mengapresiasi organisasi kelas yang dilakukan oleh dosen dalam 


\section{Histogram: Jurnal Pendidikan Matematika, 4 (2), 2020 - 523 \\ Arbain $^{*}$, Farman²}

memfasilitasi interaksi selama proses pembelajaran daring. Kalaupun ada yang bernada negatif, hanya berupa saran mereka bahwa "ada baiknya perkuliahan daring itu diselingi dengan game supaya tidak bosan dalam mengerjalan tugas". Mahasiswa juga memandang bahwa kuliah daring itu mudah dilakukan. Mereka tidak perlu datang lansung ke ruang kelas, menghemat biaya transportasi, bisa bersantai dan sambil rebahan, serta tidak perlu merias diri.

Tema lain yang juga mendapat respon positif adalah keaktifan, keleluasaan bertanya, dan fleksibelitas. Dengan kuliah daring, mahasiswa lebih aktif dan partisipatif baik dalam mengajukan pertanyaan dan mengemukakan pendapat maupun menjawab pertanyaan. Ketidakhadiran dosen secara fisik dapat menghilangkan perasaan canggung sehingga mahasiswa dengan bebas mengekpresikan pikirannya. Hal lain juga bahwa fiturfitur ruang bertanya dan diskusi pada media pembelajaran yang digunakan sangat fleksibel. Mahasiwa tidak perlu bersuara dan mengacungkan tangan untuk bertanya ataupun mengemukakan pendapat sebagaimana pada kuliah secara tatap muka. Tetapi, cukup menuliskan pertanyan berupa pesan singkat atau pada kolom komentar. Hasil penelitian ini relevan dengan penelitian (Firman \& Rahayu, 2020) bahwa mahasiswa merasa lebih mudah membangun interaksi dan komunikasi dalam pembelajaran daring.

Adapun tema-tema yang mendapat tanggapan negatif adalah tugas, koneksi internet, penguasaan materi, biaya paket data, dan beban kerja. Mahasiswa mendapatkan tugas dari dosen bertambah banyak dan menumpuk saat proses perkuliahan daring dibandingkan perkuliahan konvensional dengan tatap muka. Hasil penelitian menyatakan bahwa sistem pembelajaran daring membuat tugas-tugas semakin menumpuk dengan deadline yang singkat, sehingga menyebabkan mahasiswa kewalahan dan bingung mana yang harus dikerjakan terlebih dahulu. Tak jarang tugas yang diberikan belum dijelaskan, ditambah lagi tugasnya lebih sulit dibanding contoh yang diberikan.

Penguasaan materi turut serta menjadi sasaran mahasiswa dalam memberikan saran dan kritikan. Mahasiswa cenderung merasa kesulitan dalam memahami materi kuliah. Mereka beranggapan perkuliahan secara tatap muka lebih baik dalam memahami materi, karena dosen menjelaskan lansung secara verbal terutama mengenai materi yang sifatnya kompleks dan abstrak. Begini salah satu tanggapan dari mahasiswa, “... kuliah yang berkaitan dengan matematika perlu dijelaskan juga dengan video/gambar ...”. Fleksibilitas perangkat mobile sebagai media pembelajaran yang dilengkapi dengan fiturfitur komunikasi berupa pesan singkat, kolom diskusi, akses real time ke informasi, dan umpan balik ternyata tidak mampu memberikan pengetahuan yang lengkap kepada 


\section{Histogram: Jurnal Pendidikan Matematika, 4 (2), 2020 - 524 \\ Arbain $^{1 *}$, Farman ${ }^{2}$}

mahasiwa terutama mengenai materi matematika yang abstrak tanpa ditunjang dengan strategi pembelajaran yang cocok. Srategi pembelajaran penting untuk pembelajaran yang efektif dengan teknologi informasi (Lan, 2014; Liu et al., 2014; Lan et al., 2015).

Tantangan lain yang juga dihadapi oleh mahasiswa adalah ketidaktersediaan layanan akses internet yang memadai. Ketika kebijakan belajar dari rumah mulai diberlakukan di USN Kolaka, hampir seluruh mahasiswa yang berasal dari luar Kabupaten Kolaka memilih untuk pulang ke kampung halaman masing-masing yang sebagian besar berada di daerah pedesaan. Sebagian besar mahasiswa mengaku terkendala mengikuti pembelajaran daring terutama saat ingin menyimak materi melalui video pembelajaran atau melalui video konferensi. Hal ini disebabkan ketidaktersedian jaringan internet yang memadai di beberapa wilayah kampung mereka. Beberapa tanggapan mahasiswa, misalnya “... jaringan internet di kampung saya lelet, harus keluar rumah sampai ke gunung untuk mendapatkan jaringan internet yang agak bagus ...", “... sinyal internet hanya bisa untuk berkirim pesan singkat dan mendownload materi berbentuk pdf, sedangkat untuk membuka video online melalui YouTube dan mengakses aplikasi zoom berat ...". Hasil penelitian ini relevan dengan data BPS tahun 2018 bahwa jaringan internet diwilayah pulau Sulawesi belum merata dengan proporsi $66.13 \%$ memperoleh jaringan kuat, $27.22 \%$ jaringan lemah, dan $6.64 \%$ sisanya sama sekali belum terjangkau sinyal internet.

Mahasiswa juga terbebani dengan biaya paket data. Tanggapan mahasiswa untuk biaya paket data lebih cenderung bernada negatif dari pada positif. Mahasiswa menyatakan bahwa perkuliahan dengan sistem daring menambah pengeluaran biaya untuk pembelian paket data internet. Penggunaan konferensi video melalui aplikasi Zoom menguras data internet. Dikutip dari Merdeka.com (2020), jumlah pemakaian paket data internet dalam konferensi video atau grup video melalui aplikasi Zoom dengan resolusi 720p atau kualitas HD selama satu jam adalah 1.35 GB. Bayangkan jika setiap perkuliahan harus dilakukan melalui video konferensi dengan rata-rata mahasiswa memprogram 7 mata kuliah, maka dalam setiap minggu mahasiswa membutuhkan paket data internet minimal sebesar 9.45 GB. Belum lagi untuk kebutuhan eksplorasi materi dan bahan tugas yang menggunakan mesin pencari google.

\section{KESIMPULAN DAN SARAN}

\section{A. Kesimpulan}

Prodi Pendidikan Matematika USN Kolaka memberlakukan pembelajaran secara daring selama masa darurat Covid-19 guna menekan penyebaran Covid-19 di lingkungan kampus. Pembelajaran daring mendapat tanggapan postif dan negatif dari mahasiswa 


\section{Histogram: Jurnal Pendidikan Matematika, 4 (2), 2020 - 525 \\ Arbain $^{1 *}$, Farman ${ }^{2}$}

dengan proporsi $58.94 \%$ tanggapan untuk hal-hal positif dan $41.06 \%$ tanggapan yang bernada negatif. Tanggapan yang bernada positif diperoleh untuk aspek-aspek antara lain ketersediaan perangkat mobile, penyampaian materi, kemudahan kuliah daring, pengorganisasian kelas, jadwal kuliah, keaktifan, keleluasan bertanya, interaksi, ketertarikan, kemandirian, fleksibel, dan umpan balik. Adapun aspek-aspek yang mendapat tanggapan negatif dari responden adalah tugas, koneksi internet, penguasaan materi, biaya paket data, dan beban kerja.

\section{B. Saran}

Dari setiap keresehan mahasiswa terkait pembelajaran daring, perlu diantisipasi oleh semua pihak baik responden, institusi, maupun stakeholder yang ada. Misalnya terkait kendala biaya paket data internet, institusi dapat memberikan subsidi kuota internet kepada mahasiswa ataupun menjalin kerja sama dengan provider yang ada untuk meluncurkan program paket internet pendidikan yang murah. Seorang dosen tidak hanya perlu menyediakan konten pembelajaran bagi mahasiswanya, tetapi juga perlu untuk mengorganisasikan pembelajaran agar mahasiswa mampu mengakses, mengeksplrorasi, dan memahami konten tersebut. Untuk mendukung hal tersebut, penting bagi dosen untuk mengupayakan lingkungan sosial yang kondusif. Ekspresi afektif, kohesi kelas, dan komunikasi terbuka perlu dibangun dalam pembelajaran melalui kelas-kelas virtual. Selain itu, pengajaran juga perlu didukung oleh kesadaran dan partisipasi mahasiswa untuk belajar. Melalui pembelajaran daring, mahasiswa perlu membiasakan diri belajar secara otonom dan dapat bertanggung jawab terhadap pembelajarannya sendiri.

\section{DAFTAR PUSTAKA}

Abdul Latip. (2020). Peran literasi teknologi informasi dan komunikasi pada pembelajaran jarak jauh di masa pandemi covid-19. EduTeach : Jurnal Edukasi Dan Teknologi Pembelajaran. https://doi.org/10.37859/eduteach.v1i2.1956

Aghajani, M., \& Adloo, M. (2018). The effect of online cooperative learning on students' writing skills and attitudes through telegram application. International Journal of Instruction. https://doi.org/10.12973/iji.2018.11330a

Al-Said, K. M. (2015). Students' perceptions of edmodo and mobile learning and their real barriers towards them. Turkish Online Journal of Educational Technology.

Anshori, S. (2016). Strategi pembelajaran di era digital (tantangan profesionalisme guru di era digital). Prosiding Teтu Ilmiah Nasional Guru.

Briz-Ponce, L., Pereira, A., Carvalho, L., Juanes-Méndez, J. A., \& García-Peñalvo, F. J. (2017). Learning with mobile technologies - Students' behavior. Computers in Human Behavior. https://doi.org/10.1016/j.chb.2016.05.027 


\section{Histogram: Jurnal Pendidikan Matematika, 4 (2), 2020 - 526 \\ Arbain $^{1 *}$, Farman ${ }^{2}$}

Gon, S., \& Rawekar, A. (2017). Effectivity of E-Learning through Whatsapp as a Teaching Learning Tool. MVP Journal of Medical Sciences. https://doi.org/10.18311/mvpjms/0/v0/i0/8454

Graham, M. J., \& Borgen, J. (2018). Google Classroom. In Google Tools Meets Middle School. https://doi.org/10.4135/9781506360188.n3

Hapsari, S. A., \& Pamungkas, H. (2019). Pemanfaatan google classroom sebagai media pembelajaran online di universitas dian nuswantoro. WACANA: Jurnal Ilmiah Ilmu Komunikasi. https://doi.org/10.32509/wacana.v18i2.924

Jamaluddin, D., Ratnasih, T., Gunawan, H., \& Paujiah, E. (2020). Pembelajaran Daring Masa Pandemik Covid-19 Pada Calon Guru : Hambatan, Solusi dan Proyeksi. Karya Tulis Ilmiah UIN Sunan Gunung Djjati Bandung.

Lan, Y. J. (2014). Does second life improve mandarin learning by overseas chinese students? Language Learning and Technology.

Lan, Y. J., Sung, Y. T., Cheng, C. C., \& Chang, K. E. (2015). Computer-supported cooperative prewriting for enhancing young EFL learners' writing performance. Language, Learning and Technology.

Liu, T. C., Lin, Y. C., \& Paas, F. (2014). Effects of prior knowledge on learning from different compositions of representations in a mobile learning environment. Computers and Education. https://doi.org/10.1016/j.compedu.2013.10.019

Milman, N. B. (2015). Distance Education. In International Encyclopedia of the Social \& Behavioral Sciences: Second Edition. https://doi.org/10.1016/B978-0-08-0970868.92001-4

Moore, J. L., Dickson-Deane, C., \& Galyen, K. (2011). E-Learning, online learning, and distance learning environments: Are they the same? Internet and Higher Education. https://doi.org/10.1016/j.iheduc.2010.10.001

Pribadi, R. B. A. (2017). Media dan Teknologi dalam Pembelajaran. In Jakarta: Kencana.

Sugiyono. (2016). Metodologi Penelitian Kuantitatif, Kualitatif, dan R\&D. CV Alfabeta. https://doi.org/https://doi.org/10.3929/ethz-b-000238666

Yaumi, M. (2018). Media dan Teknologi Pembelajaran. In Jakarta. 